\title{
ПОЛЬОВІ ДОСЛІДЖЕННЯ
}

\section{ПОПЕРЕДНІ АРХЕОЛОГІЧНІ ДОСЛІДЖЕННЯ (РОЗВІДКИ) ПІД ЧАС ПРОЄКТУВАННЯ АВТОМОБІЛЬНОЇ ДОРОГИ В ОБХІД МІСТА БЕРЕЖАНИ}

\author{
Олег ОСАУЛЬЧУК (ㅁ, Зоя ІЛЬЧИШИН
}

\author{
Науково-дослідний центр «Рятівна археологічна служба» IА НАН України, \\ вул. Винниченка, 24, 79008, м. Львів, Україна, \\ e-mail:osaul.ras@gmail.com,zoya.arch@gmail.com
}

Представлено результати попередніх археологічних досліджень 2007 p. і 2017 p., проведені Науково-дослідним центром «Рятівна археологічна служба» (РАC) Інституту археології НАН України для проєктування автомобільної дороги в обхід м. Бережани Тернопільської обл. До наукового обігу введено інформацію про нові об'єкти археології та подано додаткові дані про відомі пам'ятки в околицях сіл Лісники, Лапшин, Гайок і Гиновичі.

Зазначено, що за архівно-бібліографічними даними відомо, що довкола сіл Лапшин і Гиновичі археологічні розвідки проводили в 2006 р. експедиції Михайла Филипчука та Миколи Бандрівського, проте матеріали цих обстежень недостатньо висвітлені у науковій літературі, що спричинило деяку плутанину в нумерації пам'яток, які вони виявили.

У 2007 р. експедицією РАС повторно оглянуто багатошарове поселення Гиновичі I та зібрано артефакти від пізнього палеоліту до доби раннього заліза. Тут же у 2008 р. експедицією РАС під керівництвом Богдана Сала проведено рятівні археологічні розкопки. Неподалік від цієї пам'ятки відкрито давньоруське поселення Гиновичі III. Вказано, що біля с. Лапшин нововиявлені об’єкти археології - Лапшин III-VI - репрезентують етапи заселення регіону від палеоліту до княжої доби, хоча переважають матеріали висоцької і черняхівської культур. На заліснених пагорбах в околицях с. Лісники виявлено також чотири курганні групи - Лісники I-IV - з 20 насипів, які попередньо можна датувати добою бронзи.

Констатовано, що загалом дослідженнями РАС у 2007 p. і 2017 р. виявлено 10 та уточнено інформацію про 7 відомих об'єктів археології. У результаті робіт суттєво доповнено археологічну карту регіону й узгоджено назви та нумерацію усіх пам'яток.

Зазначено, що частина давніх поселень і курганних груп розташована в межах смуги відведення під дорогу, тому до початку будівництва на них необхідно провести превентивні археологічні дослідження - розкопки, відтак їхні результати, очевидно, уточнять культурно-хронологічну належність пам'яток.

Ключові слова: археологічні розвідки, превентивні археологічні дослідження, оцінка впливу на археологічну спадщину, дорога в обхід м. Бережани, поселення, курганна група, палеоліт, доба бронзи, доба раннього заліза, пізньоримський час, висоцька культура, черняхівська культура, княжа доба.

У 2007 р. і 2017 р. експедиція Науково-дослідного центру «Рятівна археологічна служба» Інституту археології НАН України виконала археологічні вишукування (розвідки) для розроблення проєкту будівництва автомобільної дороги М-12 Стрий-Тернопіль-КіровоградЗнам'янка в обхід м. Бережани (рис. 1а) [Осаульчук, 2007; Осаульчук та ін., 2008; Черновол, 2017; Черновол, Ільчишин, 2018].

(с) Осаульчук О., Ільчишин 3., 2020 
Основна мета розвідок 2007 р. (керівник Олег Осаульчук) - виявлення всіх об’ектів археологічної спадщини в межах смуги відведення під дорогу й розроблення відповідних пам'яткоохоронних заходів. Дослідження 2017 р. (керівник Зоя Ільчишин) охопили ділянки змін проходження траси II черги обходу (рис. 1).

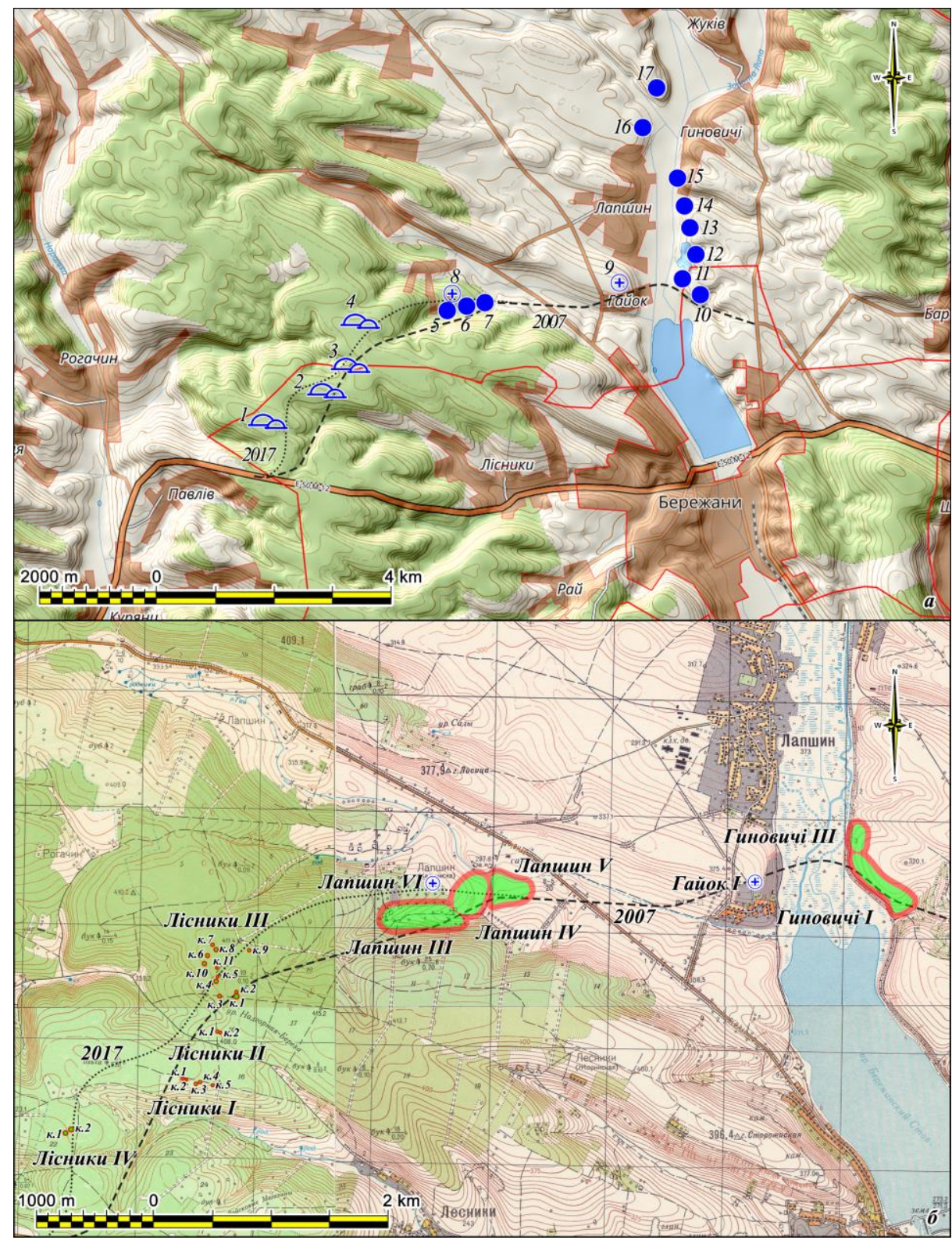

Рис. 1. $a$ - відомі пам'ятки археології в околицях сіл Лісники, Лапшин, Гайок та Гиновичі: 1 - Лісники IV, 2 - Лісники I, 3 - Лісники II, 4 - Лісники III, 5 - Лапшин III, 6 - Лапшин IV, 7 - Лапшин V, 8 - Лапшин VI, 9 - Гайок I, 10 - Гиновичі I, 11 - Гиновичі III, 12 - Гиновичі IV, 13 - Гиновичі V, 14 - Гиновичі II, 15 - Гиновичі VI, 16 - Лапшин II, 17 - Лапшин I; 6 - пам'ятки, виявлені й обстежені РАС

Fig. 1. $a$ - known archeological sites situated in the outskirts of Lisnyky, Lapshyn, Hayok and Hlynovychi villages: 1 - Lisnyky IV, 2 - Lisnyky I, 3 - Lisnyky II, 4 -Lisnyky III, 5 - Lapshyn III, 6 - Lapshyn IV, 7 - Lapshyn V, 8 - Lapshyn VI, 9 - Hayok I, 10 - Hlynovychi I, 11 - Hlynovychi III, 12 - Hlynovychi IV, 13 - Hlynovychi V, 14 - Hlynovychi II, 15 - Hlynovychi VI, 16 - Lapshyn II, 17 - Lapshyn I; 6 - sites discovered and examined by RAS 
Дослідження виконано у три етапи: підготовчий, польовий, камеральний. Кожен із них мав свої завдання.

На першому етапі опрацьовано офіційні списки (реєстри, переліки) пам'яток археології національного й місцевого значення щойно виявлених об'єктів археології та історико-архівні й бібліографічні матеріали; складено коротку історико-бібліографічну довідку про відомі об'єкти археології в межах території проєктування; проаналізовано матеріали досліджень попередніх років на предмет актуальності їхніх результатів для потреб проєктування; нанесено всі відомі об’єкти на мапи масштабу 1:50 000 - 1:100 000.

Ha другому emani суцільно обстежено трасу дороги в межах смуги відведення для виявлення слідів і решток об'єктів археології; локалізовано місця розташування відомих й нововиявлених об'єктів та прив'язано їх до топогеодезичних матеріалів масштабу 1:1 000 1:50 000; площі й розміри об'єктів встановлено за поширенням підйомного археологічного матеріалу та особливостями форм рельєфу; визначено географічні координати меж об'єктів у системі WGS-84 і CK-63 та складено відповідний каталог координат кутів полігональних об'єктів; прошурфовано території об'єктів для простеження характеру і стану збереження давніх культурних нашарувань; виконано графічну й фотографічну фіксації місць розташування об'єктів, археологічних шурфів і їхніх стратиграфічних колонок.

Ha третьому emani опрацьовано польові матеріали та визначено культурнохронологічну належність ${ }^{1}$ і наукову цінність виявлених артефактів та об’єктів археології; проаналізовано національне й міжнародне законодавство у сфері охорони культурної спадщини та проєктування і будівництва доріг; визначено наявність ризиків, потенційних загроз та ймовірні наслідки для об'єктів археологічної спадщини від реалізації проєкту будівництва; розроблено заходи з уникнення i/aбо зі зменшення чи пом'якшення негативного впливу на них; визначено види й обсяги пам'яткоохоронних робіт та розраховано їхню вартість; виготовлено науково-технічну документацію - звіт про археологічні вишукування (розвідки) та подано на розгляд обласному органу охорони культурної спадщини (Тернопільська обласна комунальна інспекція охорони пам'яток історії та культури, з 2016 р. Тернопільський обласний центр охорони та наукових досліджень пам'яток культурної спадщини (ТОЦОНДПКС)).

За архівно-бібліографічним пошуком у межах планованого будівництва відомі сім об'єктів археології. Біля сіл Лапшин і Гиновичі в липні-серпні 2006 р. експедицією Інституту археології Львівського національного університету імені Івана Франка під керівництвом Михайла Филипчука в межах виконання науково-дослідницької теми «Бурштиновий шлях» уздовж берегів р. Золота Липа виявлено чотири об’єкти археології: Лапшин I, II (рис. 1a, 16-17); Гиновичі I, II (рис. 1a, 12, 15) [Филипчук, 2007]. Того ж року Ранньоневридська археологічна експедиція відділу археології Інституту українознавства ім. І. Крип'якевича НАН України (керівник Микола Бандрівський) в околицях с. Гиновичі відкрила три поселення: Гиновичі I, II, III (рис. 1а, 10, 13, 14) [Бандрівський, 2006].

За М. Филипчуком, поселення Гиновичі I розташоване на південно-західній околиці села, безпосередньо на захід від крайніх хат, у нижній частині схилу лівого берега р. Золота Липа, має видовжену з півночі на південь форму і розміри $120 \times 40$ м (рис. 1a, 15). Тут виявлено матеріали черняхівської культури (II-IV ст.) і модерної доби (XVII-XVIII ст.) [Филипчук, 2007, c. 26-27]. Поселення Гиновичі II розташоване за 1,5 км на південь від села, на північ від джерела, що протікає в улоговині лівого берега р. Золота Липа (рис. 1a, 12). Має розміри 90×40 м і датоване XII-XIII ст. [Филипчук, 2007, с. 28-29].

\footnotetext{
1 Через сильну фрагментованість знахідок культурно-хронологічне визначення об'єктів попереднє та може бути уточнене під час археологічних розкопок.
} 
За М. Бандрівським, поселення Гиновичі І розташоване за 250-300 м на південь від села, в ур. Івахова гора, південніше дороги до м. Бережани (рис. 1a, 14), на протилежному березі яру навпроти однойменної пам'ятки М. Филипчука. Підйомний матеріал датовано пізнім палеолітом [Бандрівський, 2006, с. 1, 4]. Поселення Гиновичі II розташоване за 400-500 м на південний схід від краю села, в урочищах Під берегами і Павлове в неглибокій сідловині між двома пагорбами (рис. 1a, 13). Зібрані артефакти датовані енеолітом, добою бронзи й раннього заліза, римським часом і середньовіччям [Бандрівський, 2006, с. 4]. Поселення Гиновичі III зафіксоване за 2,3-2,5 км на південь від села на високому виступі лівого берегу р. Золота Липа і датоване палеолітом та епохою палеометалів (рис. 1a, 10) [Бандрівський, 2006, с. 5].

Неподалік від поселення Гиновичі II М. Бандрівський зафіксував рештки зруйнованого оранкою цвинтаря з матеріалами княжої доби. Можливо, це залишки грунтового могильника. Проте дослідник його не виділив окремо як об'єкт археології. У звіті також відсутня детальна локалізація [Бандрівський, 2006, с. 5].

Розвідковими роботами РАС біля сіл Лісники, Лапшин, Гайок і Гиновичі відкрито ще 10 нових об'єктів, опис яких подаємо нижче, та додатково обстежено відоме поселення (рис. 16).

У 2007 p. у лісовому масиві на північний захід від с. Лісники на відрогах гряди в межиріччі Нараївки та Золотої Липи виявлено три курганні групи: Лісники I, II та III (рис. 1a, 2-4; 16) [Осаульчук та ін., 2008]. У 2017 р. додатковими обстеженнями зафіксовано ще одну - Лісники IV (рис. 1a, 1; 16) [Черновол, Ільчишин, 2018, с. 8-9].

Курганна група Лісники I нараховує п'ять насипів і розташована за 1,5 км на північний схід від кафе при дорозі Стрий-Тернопіль та за 2,25 км на північний захід від військового цвинтаря Першої світової війни, що на північно-західній околиці села (рис. 1a, 2; 16;2, 1). Кургани займають південно-східний схил гряди, вкритої реліктовим буковим лісом, між урочищами Військові магазини та Надгірна-Береза. Насипи мають напівсферичну форму діаметром 15-19 м і висотою 0,3-1,4 м, частково зарослі чагарниками. Відстань між ними становить 35-270 м.

Курганна група 3 двох насипів Лісники II розташована за 350 м на північ-північний схід від попередньої (рис. 1a, 3; 16; 2, 2). Відстань між насипами становить 14 м, діаметр 12-14 м, а збережена висота - 0,6-0,7 м.

Курганна група Лісники III, яка нараховує 11 насипів (2 з них виявлено при повторному обстеженні у 2017 р.), розташована за 400 м на північ від курганної групи II (рис. 1a, 4; 16; 2, 3) та за 2,5 км на північний захід від околиці села, на вершині одного із відрогів гряди, витягнутої по лінії північний захід - південний схід, в ур. Надгірна-Береза. Більшість насипів розташована у старому буковому лісі на віддалі 35-110 м один від одного, частина - на колишніх вирубках із густим чагарником. Діаметр насипів становить 11-23 м, висота - 0,25-1,5 м.

Курганну групу 3 двох насипів Лісники IV локалізовано на південний захід від попередніх (рис. 1a, $1 ; 16 ; 2,4$ ), за 3 км на захід від околиці села та 1 км на північ від автодороги Стрий-Тернопіль, у лісовому масиві в ур. Грабник уздовж східного схилу одного з відрогів гряди. Діаметри збережених частин насипів становлять 21 м і 26 м, висота - до 1,5 м. Цілком імовірно, що група може простягатися далі в північно-західному напрямку вздовж верхівки залісненої гряди [Черновол, Ільчишин, 2018, с. 8].

Культурно-хронологічну належність виявлених курганних комплексів без археологічних розкопок визначити важко. Можемо припускати, що з огляду на особливості топографічного розташування, розміри насипів і результати досліджень подібних пам'яток у регіоні Передкарпаття та Верхнього Подністер'я [Пастернак, 1961, с. 257; Sulimirski, 1968, p. 144-145], вони можуть бути поховальними спорудами археологічних культур культурно-історичної спільноти шнурової кераміки, зокрема підкарпатської [Свєшніков, 1974, с. 155-158] або східногалицької групи унетицької [Бандрівський, 2011, с. 106]. Окремі насипи, вірогідно, можуть належати до старожитностей періоду доби пізньої бронзи (тщенецького кола) та доби раннього заліза. 


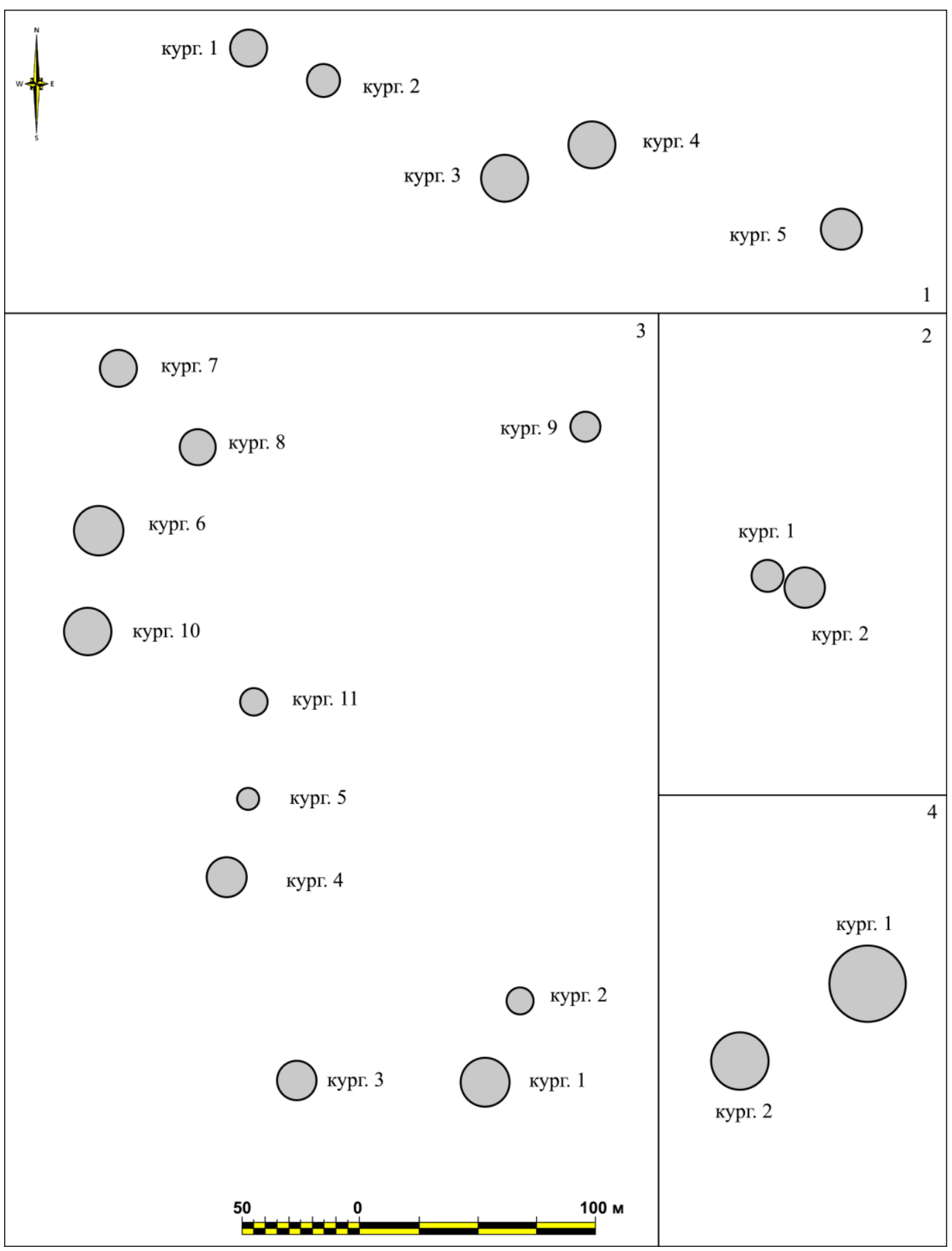

Рис. 2. Ситуаційні плани курганних груп біля с. Лісники: 1 - група Лісники I; 2 - група Лісники II; 3 - група Лісники III; 4 - група Лісники IV (виконали Павлів Д., Ільчишин 3)

Fig. 2. Situational plan of barrow groups near Lisnyky: 1 - Lisnyky I group; 2 - Lisnyky II group; 3 - Lisnyky III group; 4 - Lisnyky IV group (made by D. Pavliv, Z. Ilchyshyn)

Поблизу хут. Малиниська - південно-західного присілка с. Лапшин - відкрито групу давніх поселень - Лапшин III-V та місцерозташування - Лапшин VI (рис. 1a, 5-8; 1б) [Осаульчук та ін., 2008]. На північній околиці села розвідки М. Филипчука виявили два поселення - Лапшин I, II, розташовані поза межами проєктованого будівництва (рис. 1a, 1617) [Филипчук, 2007, с. 29-31]. 

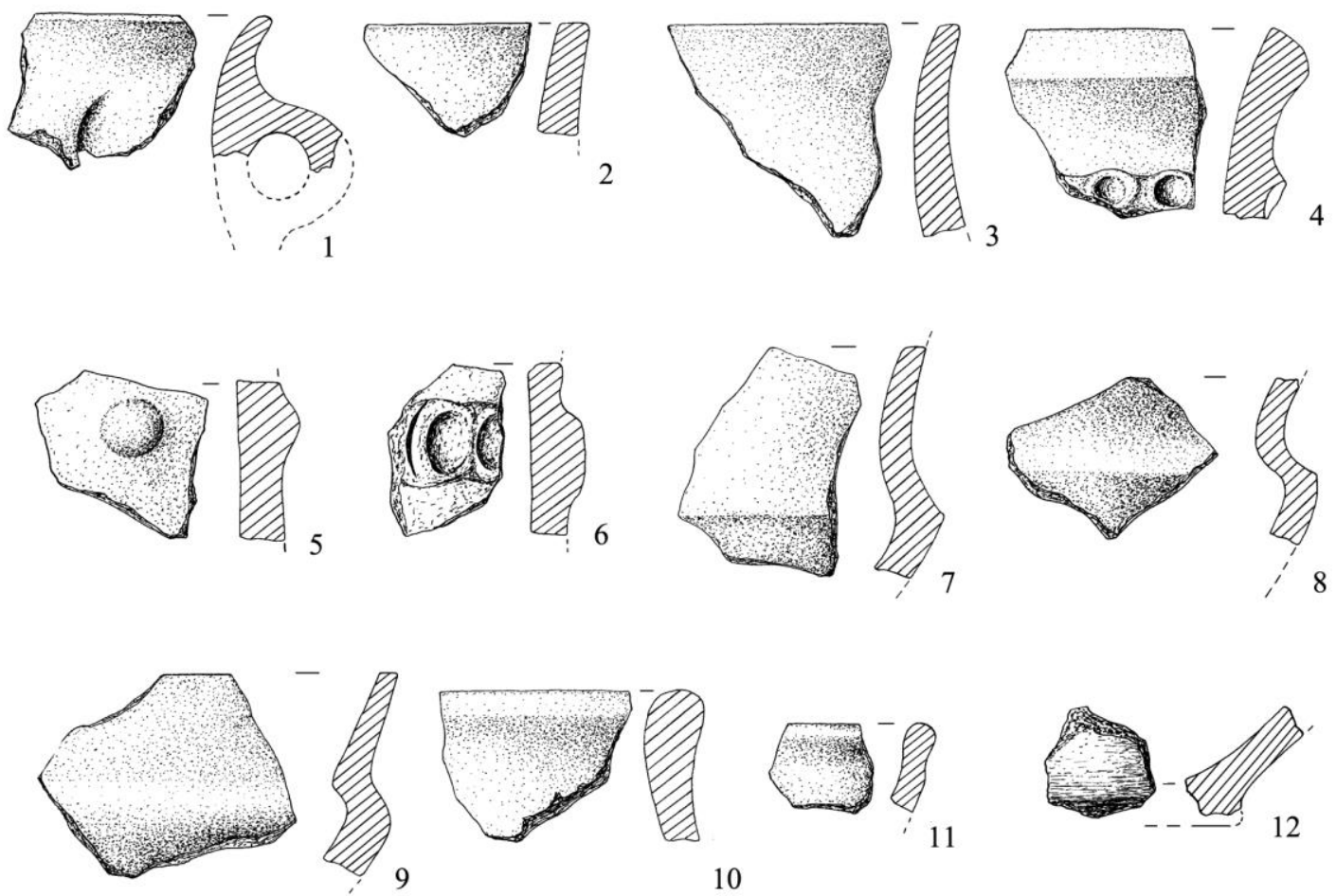

10
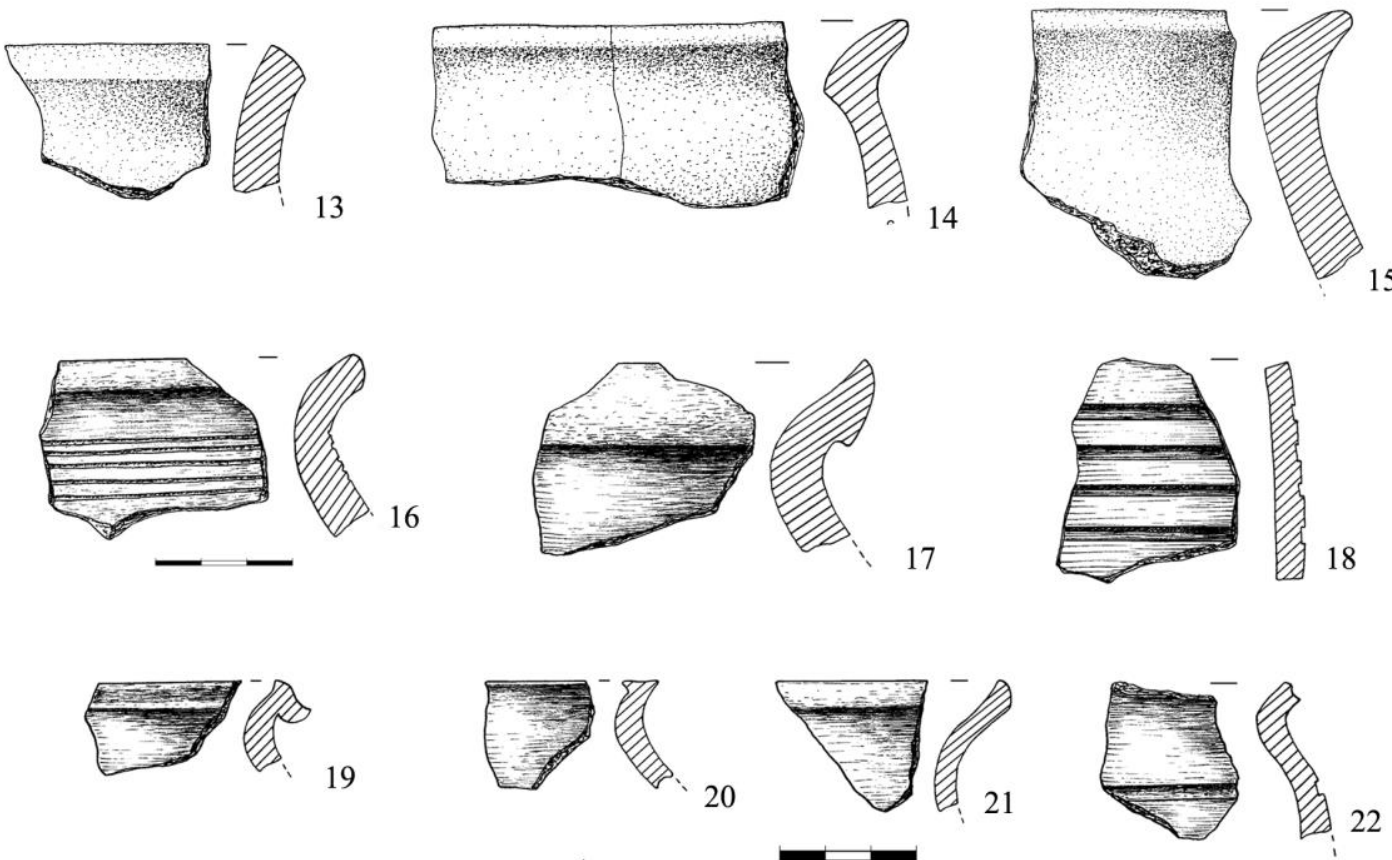

Рис. 3. Матеріали з поселення Лапшин III (виконав В. Конопля). Fig. 3. Materials from settlement Lapshyn III (made by V. Konoplia)

Багатошарове поселення Лапшин III розташоване за 1 км на південний захід від дороги Бережани-Нараїв, 300 м на південний схід від основної групи садиб хутора, у видовженій балці з пологими схилами та невеликим водотоком на їі дні - правою притокою потічка Гай (рис. 1a, 5; 16). Північна частина поселення 3 південною експозицією регулярно розорюється, що 
призводить до руйнування культурного шару, південна - задернована, західна - сильно пошкоджена під час спорудження ставка [Осаульчук та ін., 2008].

На південному схилі балки на городах виявлено скупчення перепаленої обмазки ймовірно, рештки давнього об’єкта. Грунтовий профіль представлений темно-сірими гумусованими суглинками зі значним вмістом уламків археологічних матеріалів. У шурфі на північному схилі пагорба простежено, що дерновий шар має потужність 0,05 м, від 0,05 м до 0,26 м від сучасної денної поверхні (СДП) залягають темно-сірі з коричневим слабогумусовані суглинки з вмістом уламків археологічних матеріалів, із глибини 0,26 м іде материковий шар.

Артефакти представлено численними фрагментами ліпної і кружальної кераміки доби раннього заліза (висоцька культура), римського часу (черняхівська культура) та княжої доби.

Поодинокі знахідки ліпної кераміки висоцької культури репрезентовано уламками вінець горщиків із плавно відігнутими назовні та рівно зрізаними краями (рис.3, 2-3), уламком горловини амфори з відігнутим назовні й заокругленим при завершені вінцем, під яким частково збереглося опукле у плані вушко (рис. 3, 1), та стінками і денцями горщиків, прикрашених округлими наліпами (рис. 3, 5), і пружками з пальцевими вдавленнями (рис. 3, 4, 6). Глиняна маса цих посудин щільна сіро-коричневого кольору з домішкою подрібненого шамоту та піску. На деяких фрагментах наявні сліди від розчосів віхтя.

Частина знайдених фрагментів кераміки - старожитності черняхівської культури (рис. 3, 7-11, 13-15). Кружальні горщики представлені уламками вінець, потоншених або потовщених при завершенні, косо зрізаних або заокруглених (рис. 3, 13-15). Їхнє забарвлення від сірожовтого до сіро-коричневого. На зламі вони мають колір поверхні або темно-сірий чи чорний відтінки. Колекцію доповнюють фрагменти стінок і денець та уламок петельчастої ручки.

Ліпний посуд представлений фрагментами стінок мисок 3 опуклим або ребристим профілем і відігнутим назовні краєм (рис. 3, 7, 8). Зберігся один уламок верхньої частини ліпної ребристої миски діаметром $23 \mathrm{~cm}$ світло-коричневого кольору 3 дбайливо згладженою поверхнею. Край рівно зрізаний і ледь відхилений назовні (рис. 3, 9). Товщина стінки становить 7-9 мм. Глиняна маса щільна $з$ домішкою мікрочасток шамоту.

Горщики представлені дрібними уламками вінець із відігнутими назовні та заокругленими зрізами (рис. 3, 10-11). Глиняна маса переважно грудкувата, доброго випалу та містить подрібнений шамот. Зовнішня поверхня згладжена, трохи горбкувата, де-не-де наявні сліди від розчосів віхтя.

Княжою добою датуємо фрагменти кружальної кераміки, зокрема виготовленої на повільному гончарному крузі. Ранні форми у глиняній масі містять домішки крупнозернистого піску й іноді шамоту. Зовнішня поверхня цих посудин темно-сірого кольору, злегка шерехата. Вінця манжетоподібні (рис. 3, 17), лише одне - плавно відігнуте назовні та косо зрізане (рис. 3, 16). 3а складом керамічного тіста і профілюванням верхніх частин посудин ці знахідки датуємо X-XI ст.

Посуд більш пізнього часу (XI-XII ст.) репрезентований горщиками з манжетоподібним викінченням вінець та внутрішньою закраїною. Частина із них має увігнуті до середини, розширені та рівно зрізані краї. Стінки прикрашені паралельними борозенками (рис. 3, 18-22).

Поселення Лапшин IV розташоване на схід від попереднього, 0,37-0,69 км на південний захід від великої цегляної споруди (решток ферми), що на південь від дороги Бережани-Нараїв (рис. 1a, 6; 1б). Займає пологі схили з південною, східною і північно-східною експозиціями в підніжжі гряди, на верхівці якої розташований великий сад. Із трьох сторін пагорб окреслений руслами потічка Гай (правої притоки р.Золота Липа) та його правостороннього допливу. Площа поселення видовжена 3 півдня на північ, розміри його становлять приблизно $300 \times 360$ м. У двох шурфах простежено згори дерновий шар потужністю до 0,05 м, далі 0,05-0,35 м - орний шар у вигляді темно-сірого гумусованого суглинку із вмістом археологічних матеріалів, нижче відмітки 0,35 м залягає жовто-коричневий материковий суглинок. У колекції артефактів - уламки кераміки та виробів із кременя [Осаульчук та ін., 2008]. 

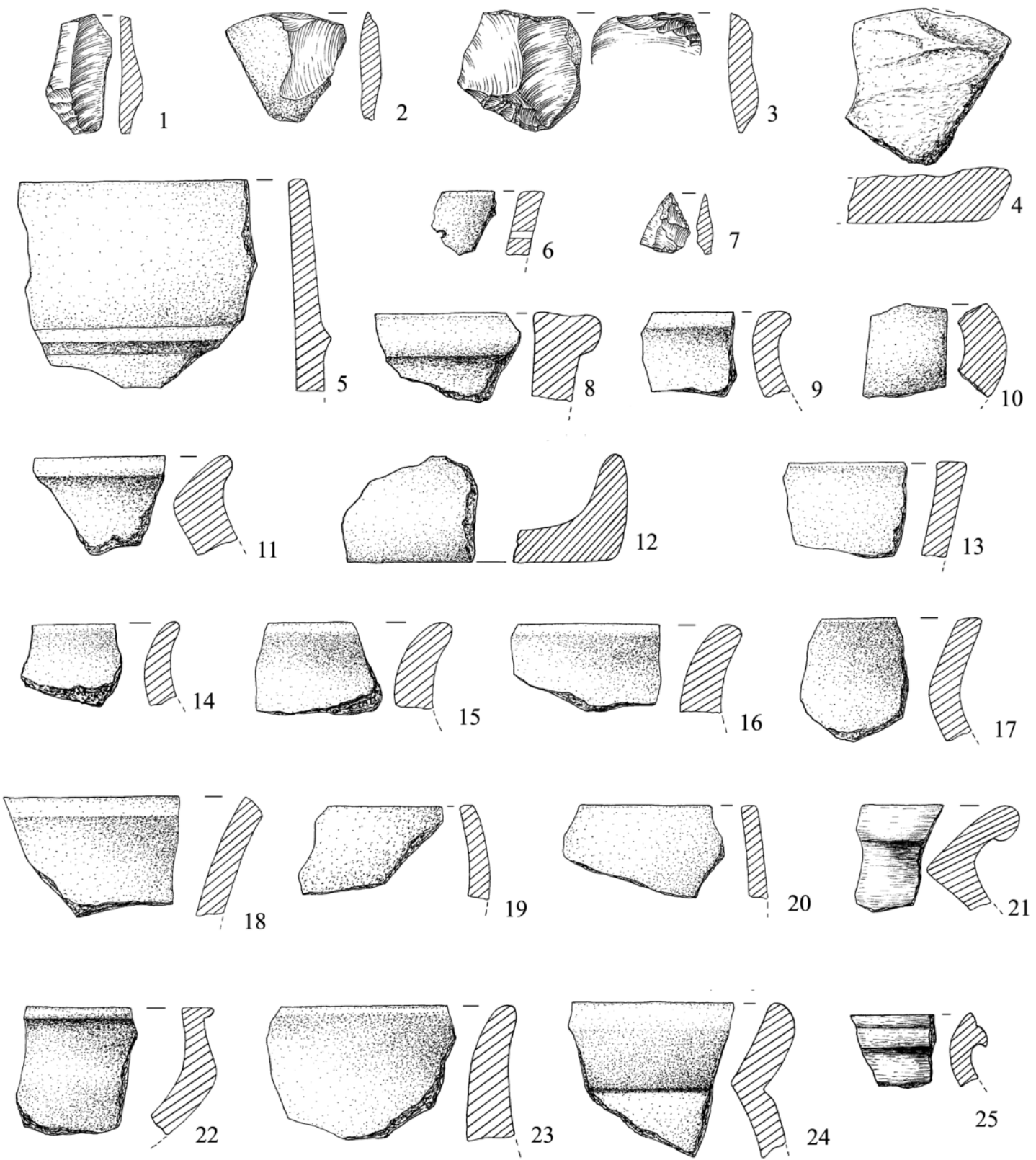

24

25
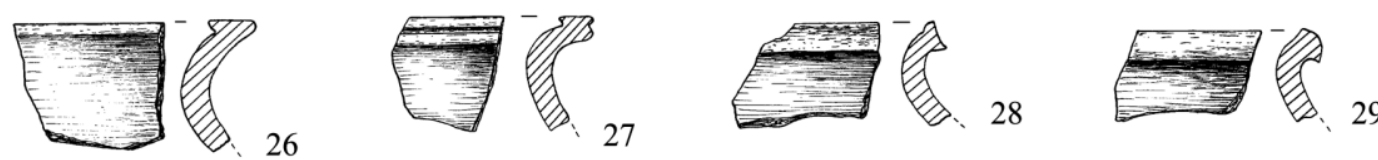

Рис. 4. Матеріали з поселень Лапшин IV (1-24), Лапшин V (25-29) (виконав В. Конопля) Fig. 4. Materials from settlement Lapshyn IV (1-24), Lapshyn V (25-29) (made by V. Konoplia)

До висоцької культури належать кілька уламків ліпного посуду та крем’яні артефакти. Останні представлені ребристо-поздовжньою пластиною із залишком жовнової кірки та кількома одно- і двобічно ретушованими відщепами (рис. 4, 1-3, 7). Серед керамічних 
знахідок - фрагменти вінець та стінок ліпних посудин світло-коричневого або світло-сірого кольору, глиняна маса яких містить домішку подрібненого шамоту. Один уламок вінця мав рівно зрізаний та відігнутий назовні край діаметром $12 \mathrm{~cm}$ та товщиною 7 мм і був прикрашений наскрізним проколом (рис. 4, 6). Другий - походив від опуклобокого банкоподібного горщика з рівно зрізаним краєм, загнутим до середини. На зовнішній поверхні в нього наявний горизонтальний пружок із ребристим профілем (рис. 4, 5). Також до висоцької культури можна віднести уламок ліпної накривки світло-коричневого кольору діаметром $14 \mathrm{~cm}$ і товщиною 13 мм. Зовнішня поверхня підправлена пальцевими згладженнями, внутрішня - дбайливо загладжена, край знахідки косо зрізаний. Виготовлений із щільної глиняної маси майже чорного кольору, з домішкою мікрочасток шамоту (рис. 4,4 ).

Найбільша кількість знахідок із поселення належать до черняхівської культури. Це переважно ліпний посуд, репрезентований фрагментами вінець горщиків, краї яких плавно відігнуті назовні, потоншені або потовщені при завершені, косо зрізані, прямі й заокруглені (рис. 4, 9, 11, 14-18, 23). Колекцію доповнює фрагмент овальної у поперечному перетині петельчастої ручки світло-сірого кольору (рис. 4,10 ). Окрему підгрупу становлять фрагменти опуклобоких і лійчастоподібних мисок світло-коричневого та сіро-коричневого кольорів із дбайливо згладженою поверхнею (рис. $4,13,19,20,22$ ). Глиняна маса ліпного посуду щільна 3 домішкою мікрочасток шамоту.

Також знайдено уламок вінця банкоподібної ліпної посудини (піфосу (?)) із профільованим, рівно зрізаним краєм діаметром близько 50 см і товщиною 15 мм. Глиняна маса сіро-жовта грудкувата 3 інтенсивною домішкою подрібненого шамоту. Поверхні сірожовті злегка горбкуваті (рис. 4,8 ).

Уламок ліпної сковорідки діаметром приблизно 34 см має частково пошкоджений i заокруглений край. Стінка висотою 3,3 см. Товщина денця становить 1,1 см. Глиняна маса темно-сіра грудкувата 3 домішкою подрібненого шамоту. Обидві поверхні світло-коричневі дбайливо загладжені (рис. 4,12 )

Кружальна кераміка цього часу репрезентована лише кількома фрагментами вінець сіроглиняних посудин, що мають різко відігнуті назовні та заокруглені при завершенні краї (рис. $4,21,24$ ). Одна знахідка датується княжою добою. Це - фрагмент вінця горщика 3 різко відігнутим назовні й рівно зрізаним краєм, оздобленим внутрішньою закраїною.

У 2017 р. під час додатково обстеження поселення зібрано знахідки, які не відрізняються від описаних, - дрібні уламки ліпного та кружального посуду черняхівської культури і княжої доби. Вирізнимо лише 11 виробів із кременю доби бронзи або раннього заліза, серед яких однобічно ретушований відщеп із залишками кірки, оброблений дрібнофасетковою крайовою лускоподібною ретушшю зі сторони спинки (рис. 5, 7-9), решта - це відходи виробництва: відщепи невеликих розмірів та луска.

У шурфі, закладеному в північно-західній частині поселення, решток культурного шару й археологічних матеріалів не зафіксовано.

Поселення Лапшин $\mathbf{V}$ розташоване на схід від двох попередніх, 0,2-0,44 км на південь від господарської споруди, що біля дороги Бережани-Нараїв, на виступі пагорба 3 пологими схилами, які мають північну і північно-східну експозиції (рис. 1a, 7; 16). Із західної та північної сторін його межі окреслені руслами потічка Гай і його правосторонньої безіменної притоки. Форма поселення видовжена зі сходу на захід, розміри близько 220×290 м. Поверхня регулярно розорюється [Осаульчук та ін., 2008].

У розвідковому шурфі до глибини 0,3 м від СДП зафіксовано темні сіро-коричневі гумусовані суглинки - орний шар - із вкрапленням археологічних матеріалів і дрібних кусків глиняної обмазки, з глибини 0,3 м - коричнево-жовті материкові суглинки.

Підйомний матеріал із поселення представлений уламками вінець кружальних горщиків XI-XII ст., які мають манжетоподібні завершення із внутрішньою закраїнкою чи 3 розширеними й рівно зрізаними краями (рис. 4, 25-29). Зовнішня поверхня цих посудин 
темно-сірого кольору злегка шерехата. Керамічне тісто добре відмулене із великим вмістом дрібно- та середньозернистого піску. Випал рівномірний.
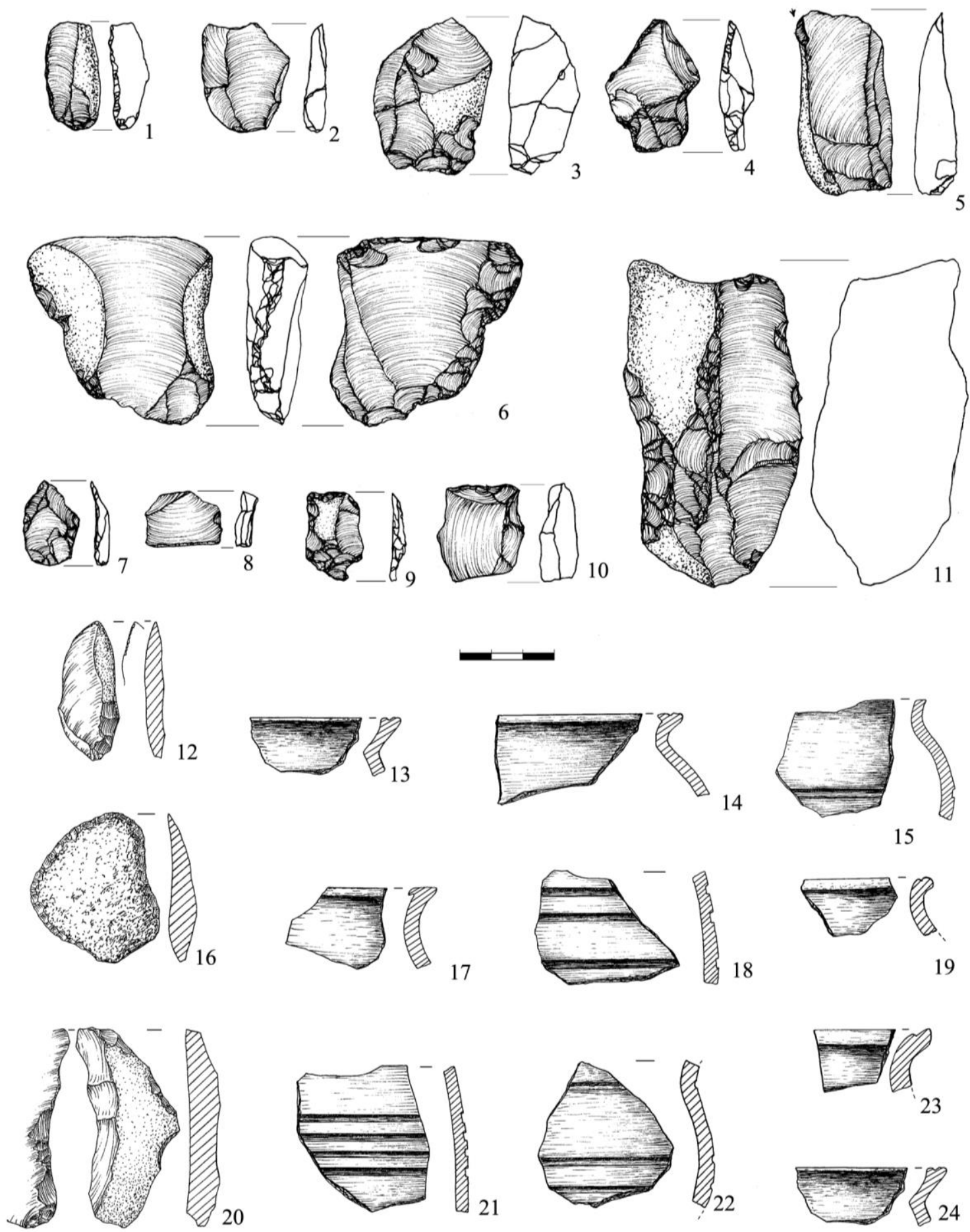

Рис. 5. Матеріали 3 поселень Лапшин V (1-5, 10-11), Лапшин IV (7-9), Гиновичі III (12-24), місцерозташування Лапшин VI (6) (виконали В. Конопля, Б. Сало)

Fig. 5. Materials from settlement Lapshyn V (1-5, 10-11), Lapshyn IV (7-9), Hlynovychi III (12-24), location Lapshyn VI (6) (made by V. Konoplia, B. Salo) 
При повторному обстеженні поселення у 2017 р., крім матеріалів княжої доби, в його північній частині на схилі пагорба виявлено 19 артефактів пізнього палеоліту - крем'яні нуклеуси різнонаправленого сколювання та їхні фрагменти. Трапляються технічні сколи ребристі первинні відщепи і пластини, а також їхні січення. Доповнюють комплекс вироби з вторинною обробкою: ретушовані відщепи, кутовий різець та кутовий скребок, виготовлений на відщепі із залишками кірки, обробленому дрібнофасетковою крайовою лускоподібною ретушшю зі сторони спинки (рис. 5, 1-5, 10-11).

На вершині пагорба в південно-західній частині цього ж поселення виявлено фрагмент вінця, із плавно відігнутим назовні краєм і з внутрішньою закраїнкою, та численні уламки стінок 3 орнаментом із паралельних горизонтальних слаборельєфних ліній. Ці матеріали можна датувати княжою добою [Черновол, Ільчишин, 2018, с. 15-17].

Місцеперебування археологічних матеріалів Лапшин VI локалізовано за 0,4 км на південний захід від крайньої групи садиб хут. Малиниська - південно-західного присілка с. Лапшин - при дорозі Нараїв-Бережани, на північ від великого саду, у верхній частині схилу з північно-східною експозицією (рис. $1 \mathrm{a}, 8$; 16). Знахідки - два пізньопалеолітичні вироби 3 кременю, один із яких - відщеп 59×58×19 мм із залишками жовнової кірки, оброблений крупнофасетковою лускоподібною ретушшю зі сторони черевця (рис. 5, 6) - зібрано на ділянці розмірами приблизно $150 \times 40 \mathrm{M}$.

У закладеному у створі проєктованої дороги шурфі не виявлено решток культурного шару і давніх артефактів. Вірогідно, що через постійне розорювання поверхні малопотужний культурний шар був зруйнований.

Місцерозташування археологічних матеріалів Гайок I зафіксовано на північній околиці однойменного села, за 0,1 км на північ від церкви, у верхній частині високої надзаплавної тераси правого берега р. Золота Липа (рис. 1a, 9). На поверхні знайдено регулярну крем'яну пластину мезоліту [Осаульчук та ін., 2008].

3а 2,5-2,7 км на південь від с. Гиновичі, у створі майбутньої дороги відкрито рештки двох поселень Гиновичі I і II [Осаульчук та ін., 2008].

Поселення Гиновичі $\mathbf{I}^{2}$ розташоване за 2,45-2,75 км на південь від сільської церкви, на високій першій надзаплавній терасі лівого берега р.Золота Липа, приблизно 16-30 м над рівнем дзеркала води [Осаульчук та ін., 2008].

Воно видовжене $з$ півночі на південь і південний схід та має розміри $110-150 \times 600$ м. Із заходу й південного заходу його межі окреслено урвистим берегом, із південної та південносхідної сторони - глибокими балками. У розвідковому шурфі простежено дерновий шар потужністю до 0,1 м, від 0,1-0,2 до 0,2-0,45 м від СДП - перевідкладений материковий суглинок, від 0,2-0,45 до 1,3 м - рештки культурного шару з темно-сірого суглинку із вкрапленням значної кількості уламків археологічних матеріалів, нижче 1,3 м залягає жовтокоричневий материковий суглинок. Виявлено матеріали трьох хронологічних горизонтів: пізнього палеоліту, доби раннього заліза і пізнього середньовіччя.

Пізньопалеолітичний комплекс представлений кам'яними виробами 3 місцевої сировини - туронського кременю ${ }^{3}$. На багатьох знахідках наявні сліди вторинної обробки [Конопля, 1998, с. 153]. Крем'яні конкреції трапляються у зрізах стінок урвистих берегів Золотої Липи і залягають близько від денної поверхні в товщі вапняків. Сировина переважно

\footnotetext{
${ }^{2}$ Пам'ятка Гиновичі I - повторно відкрите поселення Гиновичі ІІІ (за М. Бандрівським). Такі неузгодження в нумерації пам'яток біля с. Гиновичі виникли через те, що експедиції 2006-2007, 2017 р. проводили різні інституції незалежно одна від одної і їхні дії не координувалися між собою. У наукових звітах зазначено інформацію по три пам'ятки під назвою Гиновичі I і II та одну - Гиновичі III.

Тут і далі подаємо узгоджену з ТОЦОНДПКС нумерацію об’єктів археології біля с. Гиновичі (таблиця 1).

${ }^{3}$ Крем'яні артефакти 3 розвідкових досліджень на поселенні Гиновичі I опрацював Віталій Конопля співробітник Інституту українознавства ім. І. Крип’якевича НАН України (м. Львів), за що автори йому дуже вдячні.
} 
темно-сірого або майже чорного кольору з неоднорідною текстурою. Іноді знахідки мають аморфні плями та цятки світліших відтінків.

Вироби здебільша покриті патиною різної інтенсивності: від ледь помітної блідо-голубої до білої. Рідко трапляються патиновані екземпляри із природним кольором кременя або взагалі без патини. Це пояснюється особливостями мінералогічного складу конкретних конкрецій, із яких вони продукувалися.

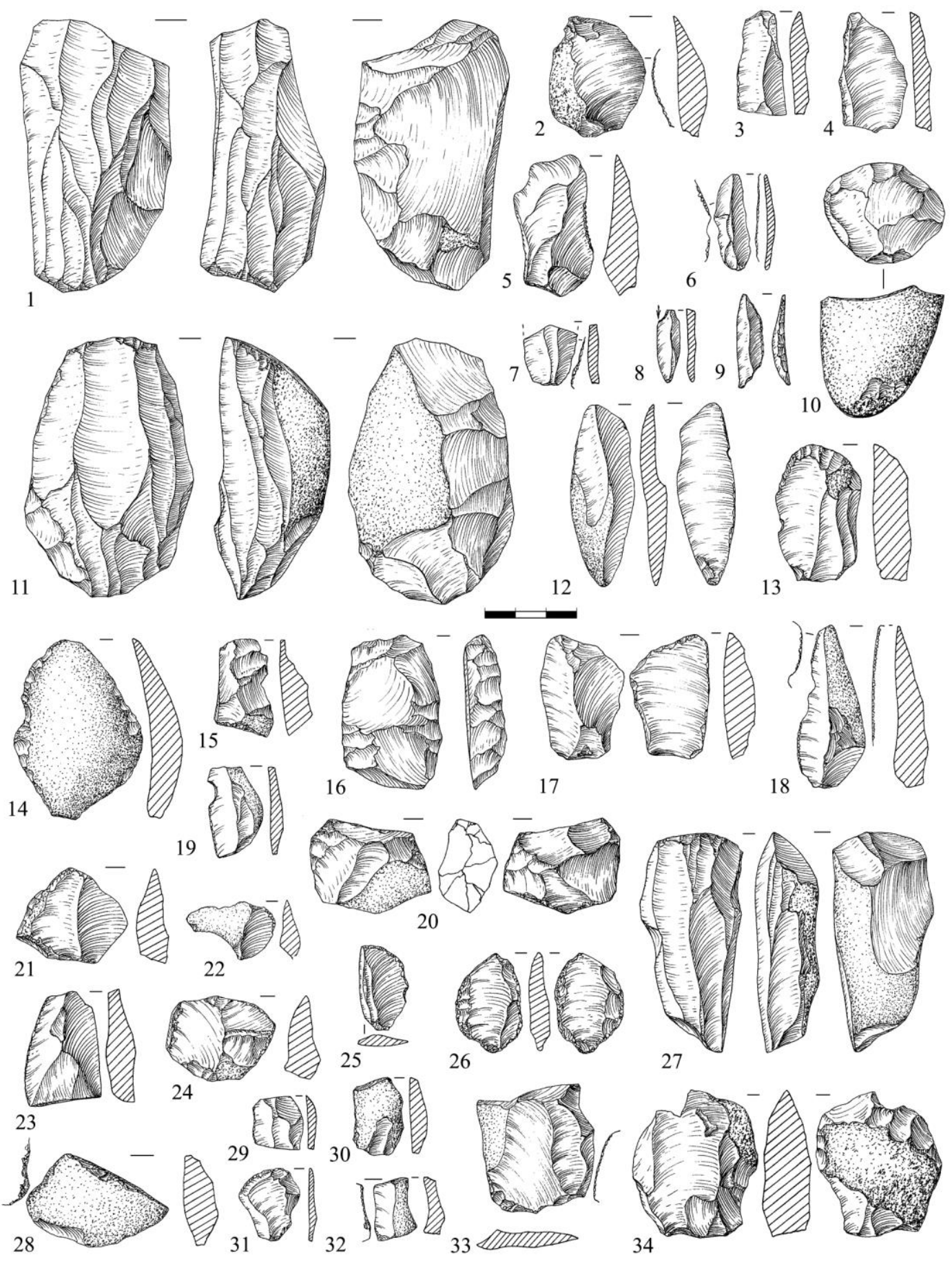

Рис. 6. Матеріали з поселення Гиновичі I (виконав В. Конопля)

Fig. 6. Materials from the settlement Hlynovychi I (made by V. Konoplia) 
Техніка розщеплення кременя простежується насамперед за двоплощинними призматичними нуклеусами (рис. $6,1,11,27 ; 6,25)$ зі скошеними ударними площадками, що мають висоту 54-90 мм, ширину 30-53 мм і товщину 20-36 мм. Тильні сторони ядрищ підправлені поперечно направленими сколами.

Основою для виготовлення знарядь праці були пластини. Знайдено дев’ять цілих розмірами $30-89 \times 10-41 \times 3-16$ мм, із ребристо-поздовжніми, поздовжньо-крайовими й поздовжніми сколами. Уламки пластин мають розміри $17-73 \times 11-39 \times 2-11$ мм. Здобуто також відщепи, частина 3 яких покрита жовновою кіркою, і сколи 3 поперечної підправки ударних площадок нуклеуса.

Артефакти із вторинною обробкою репрезентовані кінцевими скребками на нижній частині поздовжньої пластини чи на безсистемному відщепі (рис. 6, 13); одно- та двобічно ретушованими пластинами, окрайки яких загострені мікро- та дрібнозубчастою частковою чи суцільною ретушшю (рис. $6,3-7,12,14,15,17,18$ ). Виявлено вістря стріли на поздовжній пластині з обробленою крутою лускоподібною ретушшю окрайкою (рис. 6, 9), а також сокироподібне знаряддя на масивному сколі з гранями, підправленими відщепами різної величини (рис. 6,16 ).

Друга хронологічна група знахідок представлена матеріалами висоцької культури. Переважно це крем'яні вироби і в незначній кількості - фрагменти ліпного керамічного посуду. Крем’яні знахідки також виготовлено з місцевої сировини. Це, насамперед, біфаціальні нуклеуси (рис. 6, 20, 34), одно- та двобічно ретушовані відщепи (рис. 6, 29, 30, 32; 6, 14-15, 19, 21-23) та кінцеві скребки із симетричними дугоподібними та стрілчастими лезами (рис. 7, 1, 4, $6,12)$. Цікаві заготовки серпів, які не доведені до остаточного формування через низьку якість сировини. Перша - розмірами $87 \times 35 \times 19$ мм на мікросколах із конкрецій, спинки покриті жовновою кіркою. Поперечна взаємонаправлена підправка окрайок скерована до поздовжньої вісі. За задумом майстра п'ятка була б округлою, а сам серп за обрисами нагадував би асиметричний сегмент (рис. 7,2 ). Друга мала розміри $80 \times 39 \times 15$ мм, також виготовлена на мікросколах із конкрецій; спинки покриті жовновою кіркою, ретуш середньофасеткова лускоподібна, нанесена на кінці (рис. 7, 16).

Керамічний матеріал представлений незначною кількістю фрагментів стінок ліпного посуду, виготовленого із глини 3 домішкою шамоту, дрібного піску й мікрочастинок перепаленого кременю. Один з уламків має вертикально нанесені пружки із заокругленими поверхнями.

На поселенні також виявлено уламки пізньосередньовічної кружальної кераміки фрагменти вінець і денець сіроглиняних посудин.

У 2008 р. експедиція РАС під керівництвом Богдана Сала провела рятівні археологічні розкопки на пам'ятці в межах смуги відведення під дорогу. Результати цих робіт підтверджують висновки розвідкових досліджень про наявність на поселенні матеріалів від пізнього палеоліту до доби раннього заліза [Сало, 2018, с. 37-73].

Поселення Гиновичі III виявлене на північний захід від попереднього, на виступі високої надзаплавної тераси лівого берега р. Золота Липа, із західною та північно-західною експозиціями схилу, за 2,2-2,5 км на південь від церкви в с. Гиновичі (рис. 1a, 11; 1б) [Осаульчук та ін., 2008].

Пам'ятка має овальну, видовжену 3 півдня на північ, форму, розмірами близько 140×360 м. Західна межа окреслена краєм тераси, північна і північно-східна - улоговиною.

Серед підйомного матеріалу переважають речі княжої доби та пізнього середньовіччя. Також виявлено декілька крем'яних виробів із вторинною обробкою, які можуть бути старожитностями висоцької культури. Це - ребристо-поздовжні пластини, окрайки яких підправлені зі сторони черевця дрібно- та крупнофасетковою ретушшю (рис. 5, 20), кінцевий скребок на первинному відщепі з півкруглим похилим лезом (рис. 5,16$)$ та відщеп зі стрілчасто ретушованими кінцями (рис. 5,12 ). 
Матеріал княжої доби представлений уламками кружального посуду, виготовленого 3 добре відмуленої глини із великим вмістом дрібно- та середньозернистого піску й рівномірного випалу світло-коричневого і коричневого кольорів. Майже всі вінця мають відігнуті та рівно зрізані або заокруглені краї із внутрішньою закраїною (рис. 5, 13, 17, 19, 23).

Інша група кружального посуду датується пізнім середньовіччям (XV-XVIст.). Це фрагменти одного вінця та кількох стінок. Вінце відігнуте назовні, рівно зрізане біля завершення й орнаментоване ледь помітними врізними лініями [Осаульчук та ін., 2008].

Результат розвідкових робіт РАС 2007 р., 2017 р. - відкриття 10 нових різночасових об'єктів археології: 4-х курганних груп Лісники I, II, III, IV, 4-х поселень Лапшин IV, V, VI, Гиновичі III та 2-x місцерозташувань археологічних матеріалів Лапшин VI і Гайок. Вони репрезентують археологічні культури пізнього палеоліту, мезоліту, доби бронзи й раннього заліза, римського часу та пізнього середньовіччя.

Окремі насипи, вірогідно, можуть належати до старожитностей періоду доби пізньої бронзи та доби раннього заліза.

Спільно з ТОЦОНДПКС узгоджено нумерацію об’єктів археології біля с.Гиновичі (таблиця).

\section{Узгодження назв об’ектів археології біля с. Гиновичі}

\begin{tabular}{|c|c|c|c|}
\hline Остаточна назва & Назва за РАC & Назва за М. Бандрівським & Назва за М. Филипчуком \\
\hline $\begin{array}{l}\text { поселення } \\
\text { Гиновичі I } \\
\text { (рис. 1a, 10) }\end{array}$ & $\begin{array}{c}\text { Гиновичі I } \\
\text { [Осаульчук, 2007; } \\
\text { Осаульчук та ін., 2008; } \\
\text { Сало, 2018] }\end{array}$ & $\begin{array}{c}\text { Гиновичі III } \\
\text { [Бандрівський, 2006, с. 5] }\end{array}$ & \\
\hline $\begin{array}{c}\text { поселення } \\
\text { Гиновичі II } \\
\text { (рис. 1a, 14) }\end{array}$ & & $\begin{array}{c}\text { Гиновичі I } \\
\text { [Бандрівський, 2006, с. 1, 4] }\end{array}$ & \\
\hline $\begin{array}{c}\text { поселення } \\
\text { Гиновичі III } \\
\text { (рис. 1a, 11) } \\
\end{array}$ & $\begin{array}{c}\text { Гиновичі II } \\
\text { [Осаульчук, 2007; } \\
\text { Осаульчук та ін., 2008] }\end{array}$ & & \\
\hline $\begin{array}{c}\text { поселення } \\
\text { Гиновичі IV } \\
\text { (рис. 1a, 12) }\end{array}$ & & & $\begin{array}{c}\text { Гиновичі II } \\
\text { [Филипчук, 2007, c. 28-29] }\end{array}$ \\
\hline $\begin{array}{c}\text { поселення } \\
\text { Гиновичі V } \\
\text { (рис. 1a, 13) }\end{array}$ & & $\begin{array}{c}\text { Гиновичі II } \\
\text { [Бандрівський, 2006, с. 4] }\end{array}$ & \\
\hline $\begin{array}{c}\text { поселення } \\
\text { Гиновичі VI } \\
\text { (рис. 1a, 15) }\end{array}$ & & & $\begin{array}{c}\text { Гиновичі I } \\
\text { [Филипчук, 2007, c. 26-27] }\end{array}$ \\
\hline
\end{tabular}

Два об’єкти поставлено на державний облік. Поселення Гиновичі I внесено до Переліку щойно виявлених об’єктів культурної спадщини (№ 1620, Наказ управління культури Тернопільської ОДА № 16 від 27.01.2010). Поселення Гиновичі II внесено до Державного реєстру нерухомих пам'яток України за категорією пам'ятки археології місцевого значення (охоронний номер № 1621-Тр, наказ Міністерства культури і туризму України № 42 від 28.01.2014).

У межах смуги відведення II черги обходу м. Бережани розташовані курганні групи Лісники III (курган 11) i IV (курган 1), поселення Лапшин IV i V та місцерозташування Лапшин VI [Черновол, 2007, с. 19-30, 54, Додаток V]. Тому вони перебувають у зоні ризику і їм загрожує руйнування i/чи знищення під час будівництва дороги. 

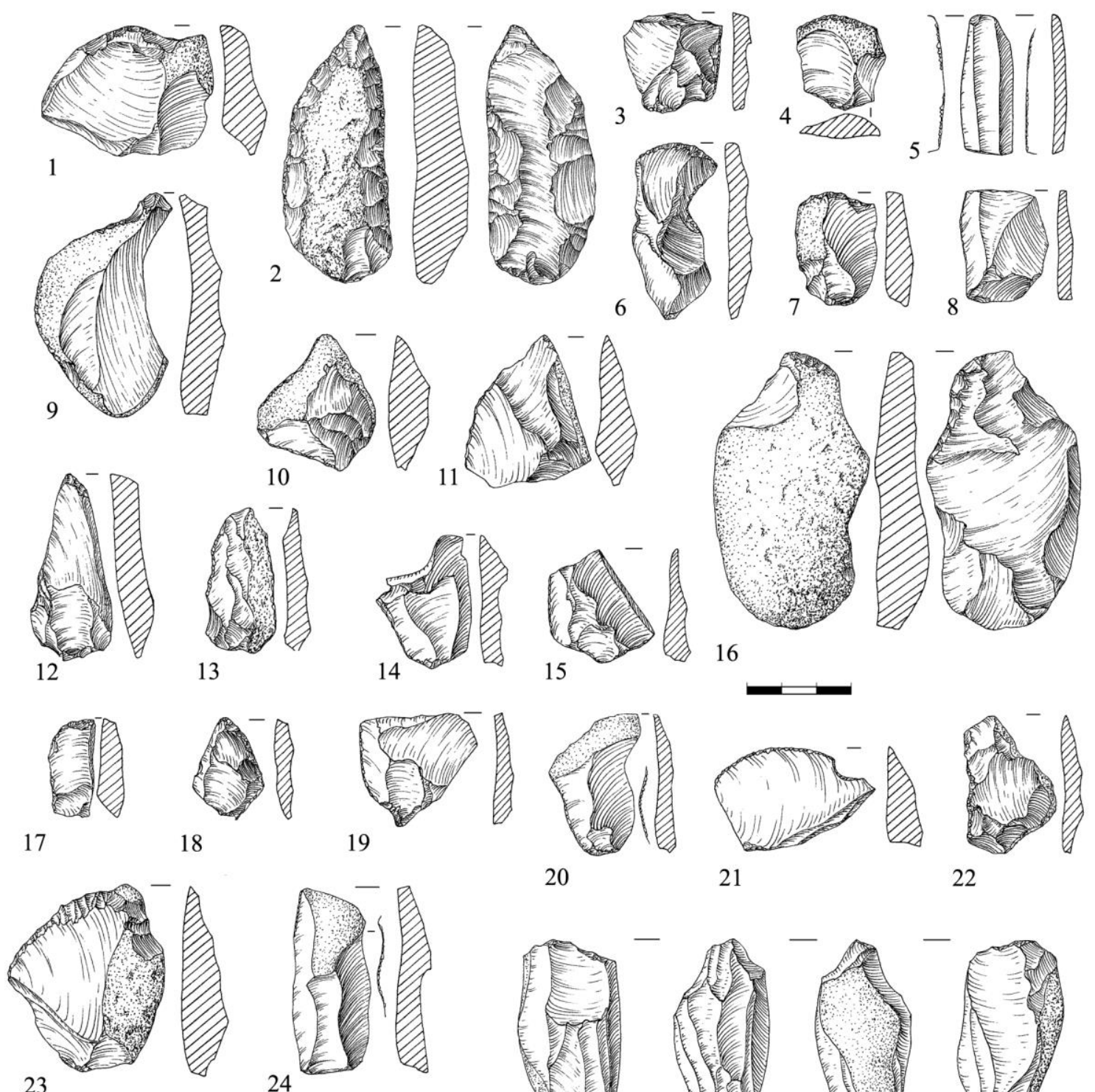

23
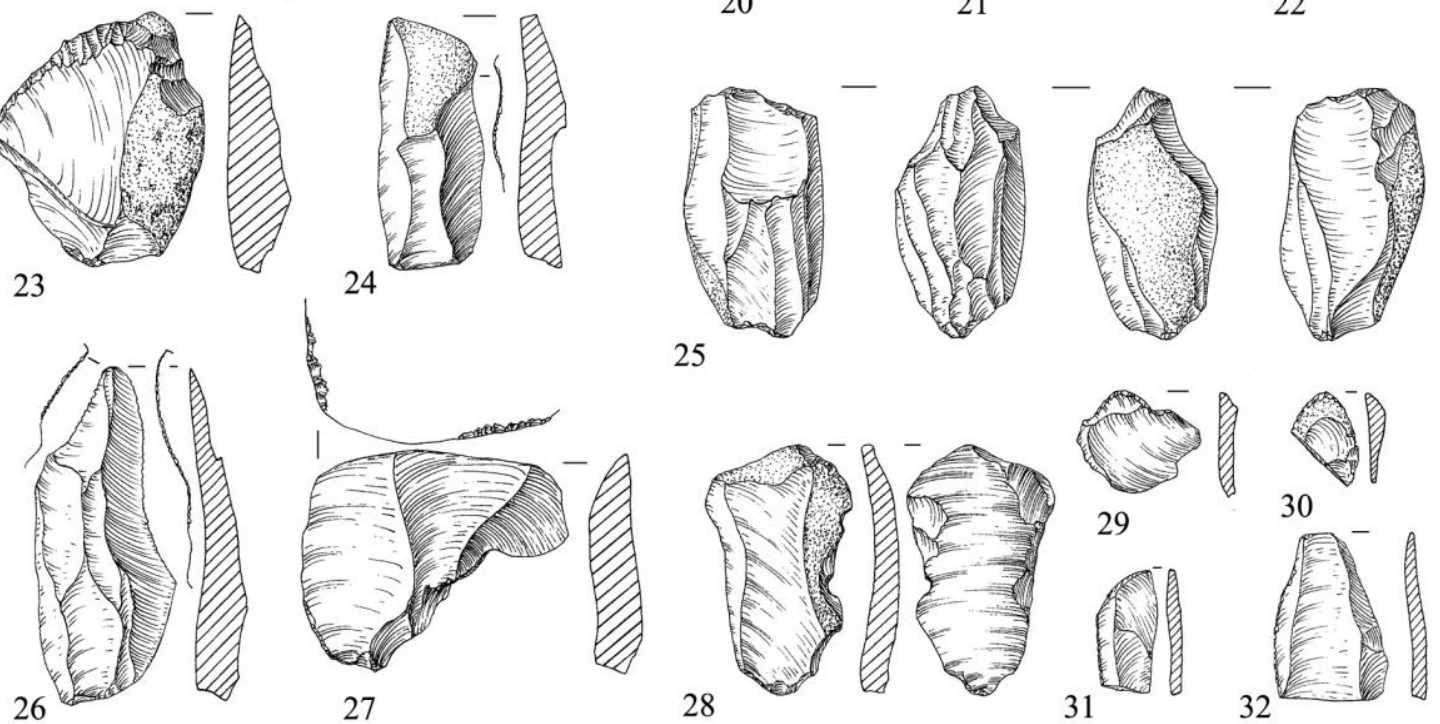

27

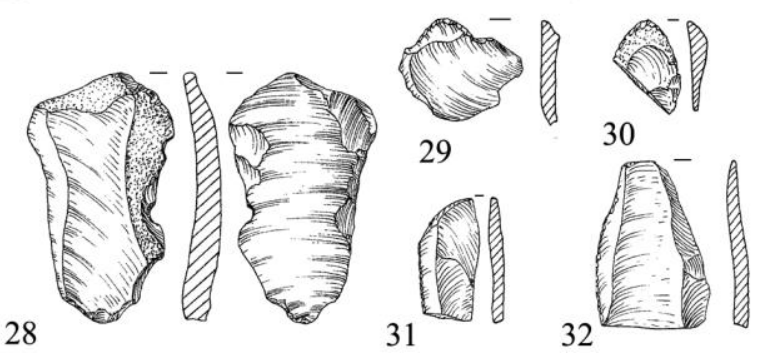

Рис. 7. Матеріали з поселення Гиновичі I (виконав В. Конопля)

Fig. 7. Materials from the settlement Hlynovychi I (made by V. Konoplia)

Оскільки реалізація цього проєкту матиме прямий вплив зі значними незворотними негативними наслідками на виявлені об'єкти археології, відповідно до положень ратифікованих Україною міжнародних конвенцій, норм чинного законодавства, під час 
розроблення пам'яткоохоронних заходів у складі цього проєкту будівництва ми застосували підхід на основі єрархії пом'якшення [Екологічна ..., 2014, с. 2-3 (Б.Зобов’язання ЄБРР, пункт 6)]. Він передбачає запобігання деструктивних впливів на культурну спадщину від початку реалізації проєкту або, якщо це неможливо, вжиття додаткових заходів, спрямованих на мінімізацію чи пом'якшення i/aбо, як останній варіант, компенсацію будь-яких потенційних залишкових негативних впливів на об’єкти археології.

Найоптимальніший варіант - будівництво дороги поза об’єктами археології та їхня державна реєстрація (облік). Однак автомобільна дорога як лінійний комплекс інженерних споруд має чіткі вимоги до радіусів кривих і поздовжніх ухилів, що в цьому разі унеможливлює будівництво конструктивних елементів дороги поза межами об’єктів археології та не дозволяє зменшити ії смугу відведення. Цю тезу добре ілюструють результати розвідок 2007 p. i 2017 р. Зміна напрямку траси дозволила уникнути ії проходження через одні пам’ятки археології, водночас у межі смуги відведення потрапили інші (рис. 1a, б).

Такі випадки потребують застосування компенсаційних пам'яткоохоронних заходів:

- превентивні або рятівні археологічні розкопки всієї території об'єкта археології в межах смуги відведення дороги до початку ії будівництва;

- археологічний нагляд за земляними роботами підготовчого етапу в межах охоронних зон об’єктів археології.

Загальний проєктний обсяг археологічних досліджень у межах II черги будівництва обходу м. Бережани становить 40 тис. м $^{2}, 3$ яких понад 18 тис. $\mathrm{m}^{2}$ - це площа розкопок [Черновол, 2007, с. 54, Додаток V].

Превентивні археологічні дослідження здобудуть і збережуть наукову інформацію про археологічні об’єкти, які назавжди стануть втраченими внаслідок будівництва. Очевидно, що за результатами масштабних розкопок можна буде визначити первинні площу й розміри пам'яток та уточнити їхню культурно-хронологічну належність.

\section{ЛІТЕРАТУРА}

Бандрівський, М. (2006). Пам’ятки села Гиновичі. Експедиційні вicmi, 1 (3), 4-5.

Бандрівський, М. (2011). Поховання прото- і ранньоунетицького типу на Верхньому Подністер'ї і проблема верхньодунайських впливів на захід Українського Лісостепу впродовж періодів BRA-1 BRA-2. Матеріали і дослідження з археології Прикарпаття і Волині, 15, 78-108.

Бандрівський, М., Білик, М. (2018). Нові палеолітичні місцезнаходження в Жукові поблизу Бережан на Тернопільщині. На пограниччі культур та етносів: взаємоконтакти як спосіб комунікації та еволюції. Тези доповідей учасників міжнародної наукової конференції, 7-10 листопада 2018 р. (с. 1721). Львів-Винники.

Екологічна та соціальна політика Європейського Банку Реконструкції та Розвитку (схвалена Радою директорів 07.05.2014). Режим доступу: https:/www.ebrd.com/downloads/research/policies/espukrainian.pdf

Конопля, В. (1998). Класифікація крем’яної сировини Заходу України. Наукові записки. Львівський історичний музей, 8, 139-157.

Осаульчук, О. (2007). Археологічні вишукування. Будівництво автомобільної дороги державного значення М-12 Стрий-Тернопіль-Кіровоград-Знам'янка на ділянці обходу м. Бережани у Тернопільській області. Том 8. Архів Науково-дослідного центру «Рятівна археологічна служба» Інституту археології Національної академії наук України. Львів.

Осаульчук, О., Милян, Т., Павлів, Д. (2008). Звіт про археологічні розвідки у смузі проектування автодороги в обхід міста Бережани Тернопільської області у 2007 р. Архів Науково-дослідного центру «Рятівна археологічна служба» Інституту археології НАНУ. Львів.

Пастернак, Я. (1961). Археологія України. Торонто.

Свєшніков I. К. (1974). Історія населення Передкарпаття, Поділля та Волині в кінці III - на початку II тис. до н. е. Київ. 
Сало, Б. (2018). Виробничий осередок пізнього палеоліту з багатошарової пам'ятки Гиновичі-І. Вісник рятівної археологіï (Acta archaeologiae conservativae), 4, 38-73.

Филипчук, М. (2007). Звіт про проведення обстежень археологічних пам'яток на узбережжі p. Золота Липа (Перемишлянський p-н Львівської області; Бережанський, Підгаєцький та Монастириський р-ни Тернопільської області) у 2006 р. Архів Інституту археології Національної академії наук України. Київ.

Черновол, Д., (2017). Звіт про археологічні вишукування (розвідки). Будівництво міжнародної автомобільної дороги державного значення М-12 Стрий-Тернопіль-Кіровоград-Знам'янка на ділянці обходу м. Бережани у Тернопільській області (від автомобільної дороги М-12 Стрий-ТернопільКіровоград-3нам'янка км 87+426 до автомобільної дороги Т-20-07 Бережани-Нараїв-Брюховичі). Архів Науково-дослідного центру «Рятівна археологічна служба» Інституту археології НАНУ. Львів.

Черновол, Д., Ільчишин, 3. (2018). Звіт про археологічні розвідки в межах будівництва автомобільної дороги М-12 на діляниі обходу м. Бережани Тернопільської області у 2017 р. Архів Науково-дослідного центру «Рятівна археологічна служба» Інституту археології НАНУ. Львів.

Sulimirski, T. (1968). Corded Ware and Globular Amphorae North-West of the Carpathians. London.

\section{REFERENCES}

Bandrivskyi, M. (2006). Pamiatky sela Hynovychi. Ekspedytsiini visti, 1 (3), 4-5.

Bandrivskyi, M. (2011). Pokhovannia proto- i rannounetytskoho typu na Verkhnomu Podnisteri i problema verkhnodunaiskykh vplyviv na zakhid Ukrainskoho Lisostepu vprodovzh periodiv BRA-1 - BRA-2. Materials and studies on archaeology of Sub-Carpathian and Volhynian area, 15, 78-108.

Bandrivskyi, M. Bilyk, M. (2018). Novi paleolitychni mistseznakhodzhennia v Zhukovi poblyzu Berezhan na Ternopilshchyni. Na pohranychchi kultur ta etnosiv: vzaiemokontakty yak sposib komunikatsii ta evoliutsii. Abstracts of Papers of the International Conference, 2018, November 7-10, Lviv-Vynnyky, p. 17-21.

Environmental and social policy of the European Bank for Reconstruction and Development (as approved by the Board of Directors at its Meeting at 07 May 2014) https://www.ebrd.com/downloads/research/policies/esp-ukrainian.pdf

Konoplia, V. (1998). Klasyfikatsiia kremianoi syrovyny Zakhodu Ukrainy. Naukovi zapysky. Lvivskyi istorychnyi muzei, 8, 139-157.

Osaulchuk, O. (2007). Budivnytstvo avtomobilnoi dorohy derzhavnoho znachennia M-12 Stryi-TernopilKirovohrad-Znamianka na diliantsi obkhodu $m$. Berezhany u Ternopilskii oblasti, 8. Arkheolohichni vyshukuvannia. Archive of the Scientific Research Center "Rescue Archaeological Service" (Institute of Archaeology, NASU), Lviv.

Osaulchuk, O., Mylian, T., Pavliv, D. (2008). Zvit pro arkheolohichni rozvidky u smuzi proektuvannia avtodorohy v obkhid mista Berezhany Ternopilskoi oblasti u 2007 r. Archive of the Scientific Research Center "Rescue Archaeological Service" (Institute of Archaeology, NASU), Lviv.

Pasternak, Ya. (1961). Archaeology of Ukraine. Toronto.

Svieshnikov I. K. (1974). Istoriia naselennia Peredkarpattia, Podillia ta Volyni v kintsi III - na pochatku II tys. do n. e. Kyiv.

Salo, B. (2018). Vyrobnychyi oseredok piznoho paleolitu z bahatosharovoi pamiatky Hynovychi-I. Acta archaeologiae conservativae, 4, 38-73.

Fylypchuk, M. (2007). Zvit pro provedennia obstezhen arkheolohichnykh pamiatok na uzberezhzhi $r$. Zolota Lypa (Peremyshlianskyi $r$-n Lvivskoi oblasti; Berezhanskyi, Pidhaietskyi ta Monastyryskyi r-ny Ternopilskoi oblasti) u $2006 r$. Archive of the Institute of Archaeology, NASU, Kyiv.

Chernovol, D. (2017). Budivnytstvo mizhnarodnoi avtomobilnoi dorohy derzhavnoho znachennia M-12 Stryi-Ternopil-Kirovohrad-Znamianka na diliantsi obkhodu $m$. Berezhany u Ternopilskii oblasti (vid avtomobilnoi dorohy M-12 Stryi-Ternopil-Kirovohrad-Znamianka km 87+426 do avtomobilnoi dorohy T-20-07 Berezhany-Naraiv-Briukhovychi). Zvit pro arkheolohichni vyshukuvannia (rozvidky). Archive of the Scientific Research Center "Rescue Archaeological Service" (Institute of Archaeology, NASU), Lviv. 
Chernovol, D., Ilchyshyn, Z. (2018). Zvit pro arkheolohichni rozvidky $\mathrm{v}$ mezhakh budivnytstva avtomobilnoi dorohy M-12 na diliantsi obkhodu m. Berezhany Ternopilskoi oblasti u $2017 \mathrm{r}$. Archive of the Institute of Archaeology, NASU, Kyiv.

Sulimirski, T. (1968). Corded Ware and Globular Amphorae North-West of the Carpathians. London.

Стаття: надійшла до редакції 12.08.2020

прийнята до друку 15.10.2020

\title{
PRELIMINARY ARCHAEOLOGICAL STUDIES (SURVEYS) ON THE PROJECT OF THE BYPASS ROAD AROUND BEREZHANY TOWN
}

\author{
Oleh OSAULCHUK, Zoya ILCHYSHYN
}

\author{
Scientific Research Centre «Rescue Archaeological Service», \\ Institute of Archaeology of the National Academy of Science of Ukraine, \\ Vynnychenka Str., 24, 79008, Lviv, Ukraine, \\ e-mail: osaul.ras@gmail.com,zoya.arch@gmail.com
}

The article offers results of preliminary archaeological investigations, conducted by Scientific Research Center «Rescue Archaeological Service» (Institute of Archaeology, National Academy of Sciences of Ukraine) in 2007 and 2017, prior to the construction project of the bypass road around Berezhany town in Ternopil region. It provides information concerning the newly discovered archeological sites as well as the elaboration of the obtainable data on formerly revealed sites in the surroundings of villages Lisnyky, Lapshyn, Hayok and Hlynovychi.

According to archival and bibliographic data, archaeological surveys were previously conducted in 2006 by the expeditions of Mykhailo Filipchuk and Mykola Bandrivsky nearby villages Lapshyn and Hynovychi. However, the summaries of these surveys are insufficiently published and besides presenting the incoherent results, which cause some confusion in the number of sites.

In 2007, expedition of Rescue Archaeological Service has re-examined the multi-layered settlement Hynovychi I, collecting the items from the Late Paleolithic to the Early Iron Age. Subsequent rescue archeological excavations were carried out in 2008 by the expedition led by Bohdan Salo.

Ancient Rus settlement Hlynovychi III was discovered adjacent to the previous site.

Around the village Lapshyn, additional archeological sites were discovered, namely Lapshyn III, IV, V, and VI, which behold several phases of the region's inhabitants starting from the Paleolithic and until the Age of Principalities. Materials of Vysotsko and Chernyakhiv cultures are predominant on these sites.

Four groups of barrows were located on the forested hills near village Lisnyky, named therefore Lisnyky I, II, III, and IV. They contain a total of 20 barrows, which could be dated to the Bronze Age.

Altogether, the explorations of 2007 and 2017 has newly discovered or identified ten archaeological sites, including settlements and burrow necropolises. Seven previously known settlement were localized due to the updated information. As a result, the archeological map of the region was significantly supplemented, with the names and numbers of archaeological sites well-coordinated.

Some of the ancient settlements and the barrow groups are located along the route of future bypass road, thus making it necessary to conduct preventive archaeological excavations. The results of intended studies will definitely clarify cultural and chronological identity of these sites.

Key words: archeological surveys, preventive archeological studies, assessments of the impact on the archeological heritage, bypass road around Berezhany town, settlement, barrow group, Paleolithic, Bronze Age, Early Iron Age, Late Antiquity, Vysotsko culture, Chernyakhiv culture, Age of Principalities. 